GRASAS Y ACEITES 70 (1)

January-March 2019, e294

ISSN-L: 0017-3495

https://doi.org/10.3989/gya.0572181

\title{
Effects of heating temperature on the tocopherol contents of chemically and physically refined rice bran oil
}

\author{
M.H. Bruscatto ${ }^{\mathrm{a}}$, V.R. Pestana-Bauer ${ }^{\mathrm{b}}$, D.M. Otero ${ }^{\mathrm{a}, \varpi}$ and R.C. Zambiazi ${ }^{\mathrm{c}}$ \\ ${ }^{a}$ Department of Science and Food Technology, Federal University of Pelotas, Campus Universitario, \\ P.O Box. 354, Pelotas/RS, 96010-900, Brazil. \\ ${ }^{\mathrm{b}}$ Institute Federal Rio Grandense, Campus Visconde da Graça, Pelotas/RS, 96060-290, Brasil \\ ${ }^{c}$ Department of Food Science, Federal University of Pelotas, Campus Universitario, \\ P.O. Box 354, Pelotas/RS, 96010-900, Brazil. \\ Corresponding author: deborah.m.otero@gmail.com
}

Submitted: 11 May 2018; Accepted: 03 September 2018

SUMMARY: The stability of $\alpha-,(\beta+\gamma)$ - and $\delta$-tocopherols present in rice bran oil at different heating temperatures has been evaluated. For this purpose, samples of rice bran oil from chemical and physical refining processes in Brazilian industries were studied. The oils were submitted to cabinet drying without air circulation in the absence of light at $100{ }^{\circ} \mathrm{C}, 140{ }^{\circ} \mathrm{C}$ and $180^{\circ} \mathrm{C}$. The samples were taken before heating and after 48,144 , $240,336,432,576,768,1008$ and $1368 \mathrm{~h}$ of heating. The analyses of tocopherols were made by high performance liquid chromatography, with a fluorescence detector. It was determined that $\alpha$-tocopherol was the compound with the fastest degradation rate at the three heating temperatures. The highest degradation rate of tocopherols in both oils occurred at $180^{\circ} \mathrm{C}$. Among the tocopherols studied, $\alpha$-tocopherol presented the lowest stability, followed by $(\beta+\gamma)$ - and $\delta$-tocopherols.

\section{KEYWORDS: Antioxidant; Chemical refining; Physical refining; Temperature}

RESUMEN: Efecto de la temperatura de refinación química y fisica de aceites de salvado de arroz sobre el contenido de tocoferoles. La estabilidad de los tocoferoles $\alpha-,(\beta+\gamma)-$ y $\delta$ presentes en los aceites de salvado de arroz a diferentes temperaturas de calentamiento fueron evaluadas. Para ello, se utilizaron muestras de aceite de salvado de arroz proveniente de los procesos de refinación química y física de industrias brasileñas. Los aceites fueron sometidos a $100{ }^{\circ} \mathrm{C}, 140{ }^{\circ} \mathrm{C}$ y $180^{\circ} \mathrm{C}$, en cabinas de secado sin circulación de aire, bajo ausencia de luz. Las muestras fueron tomadas antes de la calefacción y después de 48, 144, 240, 336, 432, 576, 768, 1008 y 1368 $\mathrm{h}$ de calentamiento. El análisis de tocoferoles fue realizado por cromatografía líquida de alta eficacia, con detector de fluorescencia. Se observó que el $\alpha$-tocoferol fue el compuesto con degradación más rápida en las tres temperaturas de calentamiento. La mayor tasa de degradación de los tocoferoles, en ambos aceites, ocurrió a la temperatura de $180^{\circ} \mathrm{C}$. Entre los tocoferoles analizados, $\alpha$-tocoferol presentó menor estabilidad, seguido por $\operatorname{los}(\beta+\gamma)$ - y $\delta$-tocoferoles.

\section{PALABRAS CLAVE: Antioxidante; Refinación física; Refinación química; Temperatura}

ORCID ID: Bruscatto MH https://orcid.org/0000-0001-5692-9909, Pestana-Bauer VR https://orcid.org/0000-00025183-211X, Otero DM https://orcid.org/0000-0001-9792-3992, Zambiazi RC https://orcid.org/0000-0001-5388-6739

Citation/Cómo citar este artículo: Bruscatto MH, Pestana-Bauer VR, Otero DM, Zambiazi RC. 2019. Effects of heating temperature on the tocopherol contents of chemically and physically refined rice bran oil. Grasas Aceites $\mathbf{7 0}$ (1), e294. https://doi.org/10.3989/gya.0572181

Copyright: (C2019 CSIC. This is an open-access article distributed under the terms of the Creative Commons Attribution 4.0 International (CC BY 4.0) License. 


\section{INTRODUCTION}

Rice bran, a by-product of the rice milling process, constitutes about $10 \% \mathrm{wt}$ of rough rice grain and 18 to $22 \%$ oil (saponifiable lipids including glycolipid and phospholipids, and unsaponifiable lipids, including tocopherols, tocotrienols, oryzanol, sterols, and carotenoids), making it the richest oil source from a grain by-product (Salem et al., 2014). The antioxidant compounds in rice bran have proven health benefits as well as antioxidant characteristics for improving the storage stability of foods (Azlan et al., 2008). Rice bran contains relatively high concentrations of tocopherols compared to other oil seeds, which increases its nutritive value (Ko et al., 2008; Salem et al., 2014).

$\alpha-, \beta-, \gamma$ - and $\delta$-tocopherols, which differ in the number and localization of the methyl groups in the aromatic ring, contain vitamin E. Tocopherols are monophenolic compounds and are characterized by a lateral chain saturated with 3 quiral carbons of asymmetry in positions 2, 4 and 8 (Morrissey and Sheehy, 1999; Cunha, 2006; Flohé, 2006; Rosli et al., 2006; Martins, 2006).

$\alpha$-tocopherol is one of the most abundant natural antioxidant in nature, and is found in practically all vegetable oils. It is recognized for exerting biological effects that protect cellular membranes and for increasing the stability of oils and fats. $\alpha$-tocopherol presents high biological activity as vitamin $\mathrm{E}$, which is twice superior to $\beta$ - and $\gamma$ - and 100 times superior to $\delta$-tocopherol (Nolasco et al., 2004; Romero et al., 2007; Pestana et al., 2008a).

Tocopherols are oxidized by oxidizing agents, especially in the presence of heat, light, metals and alkaline mediums. These compounds oxidize slowly in an oxygen-charged atmosphere, in the absence of light, even at temperatures above $200{ }^{\circ} \mathrm{C}$. However, in the presence of oxygen, the stability of $\alpha$-tocopherol is reduced by half at each $10^{\circ} \mathrm{C}$ increase when exposed to temperatures higher than $40{ }^{\circ} \mathrm{C}$ (Martins, 2006).

The oxidative degradation of tocopherols is strongly influenced by the oxidation of unsaturated fatty acids. The degradation of tocopherols increases with lipid oxidation, a high concentration of oxygen and the presence of free radicals (Zambiazi, 1997; Pestana, et al., 2009). Research carried out by Player, Kim, Lee and Min (2006) to evaluate the stability of $\alpha-, \gamma$ - and $\delta$-tocopherols during the oxidation of soybean oil at $50{ }^{\circ} \mathrm{C}$ demonstrated that $\alpha$-tocopherol showed higher degradation than $\gamma$-and $\delta$-tocopherols. In accordance with the same authors, the degradation of tocopherols increases with the level of oxidation in the oil; $\alpha$-tocopherol was completely destroyed at 16 days while $\gamma$ - and $\delta$-tocopherols 1 were still present after 24 days of heating.

The content and proportion of the tocopherols present in oil depends on a number of factors, such as the oil extraction and purification process, storage time and conditions, as well as the type of refining and conditions, which may be chemical or physical (Martins et al., 2006).

Unacceptable materials are separated from crude oils by using a different type of refining process. Chemical refining includes degumming, neutralizing, bleaching, winterizing and, finally, deodorizing stages. In physical refining, the removal of free fatty acids by chemical neutralization is replaced by simultaneous de-acidification/de-odorization (Tasan and Demirci, 2005)

The aim of this study was to evaluate the stability of tocopherols $(\alpha, \delta-\gamma)$ against continuous heating at different temperatures $\left(100^{\circ} \mathrm{C}, 140^{\circ} \mathrm{C}\right.$ and $\left.180^{\circ} \mathrm{C}\right)$ of chemically and physically refined rice bran oil.

\section{MATERIALS AND METHODS}

\subsection{Reagents and samples}

The solvents used in the study were isooctane, isopropanol, acetonitrile and acetone (Vetec, Rio de Janeiro, Brazil). Standards of $\alpha$ - tocopherol ( $99 \%$, Merck, Darmstadt, Germany), $\gamma$-tocopherol (> $96 \%$, Sigma) and $\delta$-tocopherol (> 90\%, sigma), were also used.

Samples of chemically refined rice bran oil (Oryza sativa) were donated by the rice bran oil processing industry (Indústria Rio-Grandense de Óleos Vegetais Irgovel (Pelotas-RS)). The physically refined rice bran oil was donated by the rice bran oil processing industry (Helmut Tessmann (Camaquã/RS)).

\subsection{Procedure}

Chemically and physically refined rice bran oil was heated in the absence of light. For this purpose, $300 \mathrm{~mL}$ of each type of oil were placed separately in open glass recipients with $500 \mathrm{~mL}$ capacity. The oils were previously heated until they reached the temperature of the experiment and after that they were placed in the interior of the heater at the predetermined temperature. The experiments were conducted at temperatures of $180{ }^{\circ} \mathrm{C} \pm 2,140{ }^{\circ} \mathrm{C} \pm 2$ and $100{ }^{\circ} \mathrm{C} \pm 2$, to simulate the cooking and frying conditions of many food preparations.

The samples were collected at pre-determined time intervals and stored in amber-colored flasks which were frozen at $-18^{\circ} \mathrm{C}$ until analysis.

The collection of samples was carried out every $48 \mathrm{~h}$ until $432 \mathrm{~h}$ of heating for oil at $180^{\circ} \mathrm{C}$. The oil samples heated at $140{ }^{\circ} \mathrm{C}$ were collected at the same intervals until $432 \mathrm{~h}$ of heating, and the samples were collected every $72 \mathrm{~h}$ until $576 \mathrm{~h}$, and after each $120 \mathrm{~h}$ until $1008 \mathrm{~h}$ of heating. The same procedure was followed for the oil heated at $100{ }^{\circ} \mathrm{C}$ until $1368 \mathrm{~h}$ of heating. The final point of sample collection at different temperatures was defined when $\alpha$-tocopherol was absent from the oil sample. 


\subsection{Quantification of tocopherols}

The analysis of tocopherols was carried out in accordance with the methodology described by Pestana et al., 2008b. Approximately $250 \mathrm{mg}$ of rice bran oil were weighed and diluted in acetone to the volume of $5 \mathrm{~mL}$. The mixture was centrifugated for 6 minutes at $9000 \mathrm{rpm}$ in a micro-centrifuge (NT800 Nova Técnica, Piracicaba, Brazil), and the organic phase was removed to a vial with a $1.5 \mathrm{~mL}$ capacity. Aliquots of 20 to $40 \mu \mathrm{L}$ were injected into the liquid chromatograph.

The HPLC separations were performed at $25{ }^{\circ} \mathrm{C}$ with a constant flow rate of $1 \mathrm{~mL} \cdot \mathrm{min}^{-1}$. Fluorescent detection, with excitation and emission wavelengths set at 290 and $330 \mathrm{~nm}$, was used for the tocopherols. The initial and final mobile phases were 50:40:10 (A) and 30:65:5 (B) acetonitrile-methanol-isopropanol mixtures (v/v/v), respectively. Separation was carried out with an isocratic elution of phase A for 5 min., changing by a linear gradient for $10 \mathrm{~min}$. to phase B, followed by $5 \mathrm{~min}$. of isocratic elution with phase $B$ and then returning to phase $A$ in $5 \mathrm{~min}$. The time of analysis was 15 min. Class-VP software was used to acquire and process the data. Standards of $\alpha-, \gamma$ - and $\delta$ - tocopherols were used for external calibration curves.

\subsection{Statistical analysis}

The design was completely randomized in a $2 \times 10$ bi-factorial scheme, with two forms of refining and ten times of evaluating. To analyze the data, the means and respective standard deviations were performed, as well as the analysis of variance (p $<$ 0.05 ). For the quantitative variables that presented significance, regression analysis was performed; while for the qualitative analysis, the $T$ test $(\mathrm{p}<$ 0.05 ) was performed. All analyses were performed in triplicate.

\section{RESULTS}

$\alpha$-tocopherol was the major tocopherol found in the chemically refined rice bran oil (OCR) as well as in the physically refined rice bran oil (OPR), followed by $(\beta+\gamma)$ - and $\delta$-tocopherols. The content of $(\beta+\gamma)$ - and $\delta$-tocopherols was practically the same in both oils. However, the chemically refined oil showed the highest level of $\alpha$-tocopherol (time zero, Table 1)

The content of $\alpha$-tocopherol in the OCR showed a gradual reduction until $432 \mathrm{~h}$ of heating at 100 ${ }^{\circ} \mathrm{C}$, reaching a $28,65 \%$ loss in this period. After this period its degradation was more intense and in the period of $1368 \mathrm{~h}$ it presented total degradation.

The content of $\alpha$-tocopherol in OPR showed a lower degradation rate, reaching a loss of only $8.53 \%$ in the period of $432 \mathrm{~h}$ of heating. During the period from $432 \mathrm{~h}$ to $1008 \mathrm{~h}$ of heating, the tocopherol showed a loss of $47.56 \%$; therefore, the loss was lower to that presented by the chemically refined oil. The loss in $\alpha$-tocopherol was only $63.69 \%$ upon completing $1368 \mathrm{~h}$ of heating, also lower than that presented by the chemically refined oil. Therefore, at $100{ }^{\circ} \mathrm{C}$, the loss in $\alpha$-tocopherol in chemically refined oil was lower than in physically refined oil.

TABLE 1. Tocopherol contents $(n=3$, mean \pm SD), in chemically refined rice oil and physically refined oil subjected to a temperature of $100^{\circ} \mathrm{C}$

\begin{tabular}{|c|c|c|c|c|c|c|}
\hline \multirow[b]{2}{*}{ Time (h) } & \multicolumn{2}{|c|}{$\begin{array}{c}\alpha \text {-tocopherol } \\
\left(\mathrm{mg} \cdot 100 \mathrm{~g}^{-1}\right)\end{array}$} & \multicolumn{2}{|c|}{$\begin{array}{c}\gamma \text {-tocopherol } \\
\left(\mathrm{mg} \cdot 100 \mathrm{~g}^{-1}\right)\end{array}$} & \multicolumn{2}{|c|}{$\begin{array}{c}\text { d-tocopherol } \\
\left(\mathrm{mg} \cdot 100 \mathrm{~g}^{-1}\right)\end{array}$} \\
\hline & OCR* & OPR** & OCR* & OPR** & OCR* & OPR $^{* *}$ \\
\hline 0 & $32.84 \pm 1.5^{\mathrm{a}}$ & $25.67 \pm 1.9^{\mathrm{b}}$ & $9.91 \pm 1.1^{\mathrm{a}}$ & $9.22 \pm 0.8^{\mathrm{a}}$ & $0.77 \pm 0.1^{\mathrm{a}}$ & $0.71 \pm 0.1^{\mathrm{a}}$ \\
\hline 48 & $32.17 \pm 2.0^{\mathrm{a}}$ & $25.15 \pm 1.9^{\mathrm{b}}$ & $8.84 \pm 0.3^{\mathrm{a}}$ & $8.54 \pm 0.9^{\mathrm{a}}$ & $0.77 \pm 0.1^{\mathrm{a}}$ & $0.63 \pm 0.1^{\mathrm{b}}$ \\
\hline 144 & $31.51 \pm 2,9^{\mathrm{a}}$ & $25.01 \pm 0.8^{\mathrm{b}}$ & $8.59 \pm 0.5^{\mathrm{a}}$ & $7.09 \pm 0.8^{\mathrm{b}}$ & $0.73 \pm 0.1^{\mathrm{a}}$ & $0.63 \pm 0.1^{\mathrm{a}}$ \\
\hline 240 & $26.88 \pm 2.3^{\mathrm{a}}$ & $23.93 \pm 1.2^{\mathrm{b}}$ & $8.13 \pm 0.8^{\mathrm{a}}$ & $6.85 \pm 0.4^{b}$ & $0.69 \pm>0.1^{\mathrm{a}}$ & $0.53 \pm 0.1^{\mathrm{b}}$ \\
\hline 336 & $25.77 \pm 0.8^{\mathrm{a}}$ & $23.83 \pm 1.0^{\mathrm{a}}$ & $8.10 \pm 0.2^{\mathrm{a}}$ & $6.71 \pm 0.3^{\mathrm{b}}$ & $0.69 \pm>0.1^{\mathrm{a}}$ & $0.52 \pm 0.1^{\mathrm{b}}$ \\
\hline 432 & $23.43 \pm 2,6^{\mathrm{a}}$ & $23.48 \pm 0.9^{\mathrm{a}}$ & $7.99 \pm 0.3^{\mathrm{a}}$ & $6.37 \pm 0.6^{\mathrm{b}}$ & $0.64 \pm>0.1^{\mathrm{a}}$ & $0.52 \pm>0.1^{\mathrm{a}}$ \\
\hline 576 & $18.43 \pm 1,4^{\mathrm{a}}$ & $20.49 \pm 1.8^{\mathrm{a}}$ & $6.82 \pm 1.1^{\mathrm{a}}$ & $5.60 \pm 0.2^{\mathrm{b}}$ & $0.61 \pm>0.1^{\mathrm{a}}$ & $0.49 \pm>0.1^{\mathrm{a}}$ \\
\hline 768 & $14.46 \pm 1.3^{\mathrm{b}}$ & $20.45 \pm 1.7^{\mathrm{a}}$ & $6.07 \pm 0.5^{\mathrm{a}}$ & $5.51 \pm 0.3^{\mathrm{a}}$ & $0.60 \pm>0.1^{\mathrm{a}}$ & $0.48 \pm>0.1^{\mathrm{a}}$ \\
\hline 1008 & $6.29 \pm 1.1^{\mathrm{b}}$ & $13.46 \pm 0.5^{\mathrm{a}}$ & $4.16 \pm 0.6^{\mathrm{a}}$ & $3.70 \pm 0.4^{\mathrm{a}}$ & $0.53 \pm>0.1^{\mathrm{a}}$ & $0.42 \pm 1.0^{\mathrm{a}}$ \\
\hline 1368 & $\mathrm{Nd}$ & $9.32 \pm 0.6^{\mathrm{a}}$ & $2.00 \pm 0.2^{\mathrm{a}}$ & $2.38 \pm 0.4^{\mathrm{a}}$ & $0.51 \pm>0.1^{\mathrm{a}}$ & $0.28 \pm 1.0^{\mathrm{b}}$ \\
\hline
\end{tabular}

Values followed by lowercase letters between the columns (OCR and OPR) do not differ from each other at $5 \%$ significance by the T test $\mathrm{t}(\mathrm{p}>0.05)$.

Nd- not detected

*OCR: chemically refined oil

**OPR: physically refined oil 
The content of $(\beta+\gamma)$-tocopherol in the chemically refined oil showed a degradation of $19.37 \%$ in the period of $432 \mathrm{~h}$ of heating, reaching losses of $58.02 \%$ at $1008 \mathrm{~h}$ of heating. The highest degradation rate of the $(\beta+\gamma)$-tocopherol occurred at the end of the heating period $(1.368 \mathrm{~h})$, when its content presented a reduction of $79.82 \%$.

In the physically refined oil, the reduction of $(\beta+\gamma)$-tocopherol was also greater, $30.91 \%$ at $432 \mathrm{~h}$ of heating. However, the highest percentage of degradation occurred in the period of $1008 \mathrm{~h}(59.87 \%)$ and at the end of the heating period $(1368 \mathrm{~h})$, the reduction of the $(\beta+\gamma)$-tocopherol $(74.19 \%)$ was lower when compared to the chemically refined oil.

The content of $\delta$-tocopherol in the chemically refined oil showed a reduction of $16.88 \%$ in the period of $432 \mathrm{~h}$ and $37.77 \%$ at the end of the heating period $(1368 \mathrm{~h})$. In the physically refined oil, the content of this tocopherol showed a more intense decrease than the content of $\delta$ - tocopherol in the chemically refined oil, with a reduction of $26.76 \%$ in the period of $432 \mathrm{~h}$ and of $60.56 \%$ at the end of the heating period $(1368 \mathrm{~h})$.

Thus, at the heating temperature of $100{ }^{\circ} \mathrm{C}$, it was observed that tocopherols present in the physically refined oil remained more stable than the tocopherols present in the chemically refined oil, which can be observed in Figure 1a.
The content of $\alpha$-tocopherol in the chemically refined oil heated at $140{ }^{\circ} \mathrm{C}$ (Table 2) showed a degradation of $32.19 \%$ at $432 \mathrm{~h}$ and its degradation was $100 \%$ at $1008 \mathrm{~h}$ of heating. Once again, the content of $\alpha$-tocopherol in physically refined oil presented a reduction of only $59.80 \%$ at the end of the period of $1008 \mathrm{~h}$.

The OCR heated at $140{ }^{\circ} \mathrm{C}$ showed a gradual reduction in the $(\beta+\gamma)$-tocopherol in all heating periods, presenting a degradation of $87.08 \%$ at the end of the heating period $(1008 \mathrm{~h})$. The $(\beta+\gamma)$-tocopherol in OPR presented a reduction of $59.65 \%$ compared to the $41.57 \%$ reduction in $(\beta+\gamma)$-tocopherol in the chemically refined oil during the same period, which means that more than half of its initial content had already been degraded.

Once again, the content of $(\beta+\gamma)$-tocopherol in the physically refined oil presented a more rapid degradation during the heating period than in the chemically refined oil. However, at the end of the exposure time to heating, it presented very similar reduction percentages.

The content of $\delta$-tocopherol in the chemically refined oil showed a gradual reduction until reaching the period of $432 \mathrm{~h}$ of heating $(29.87 \%)$. After this period its degradation was more intense, reaching a reduction of $44.16 \%$ upon completion of
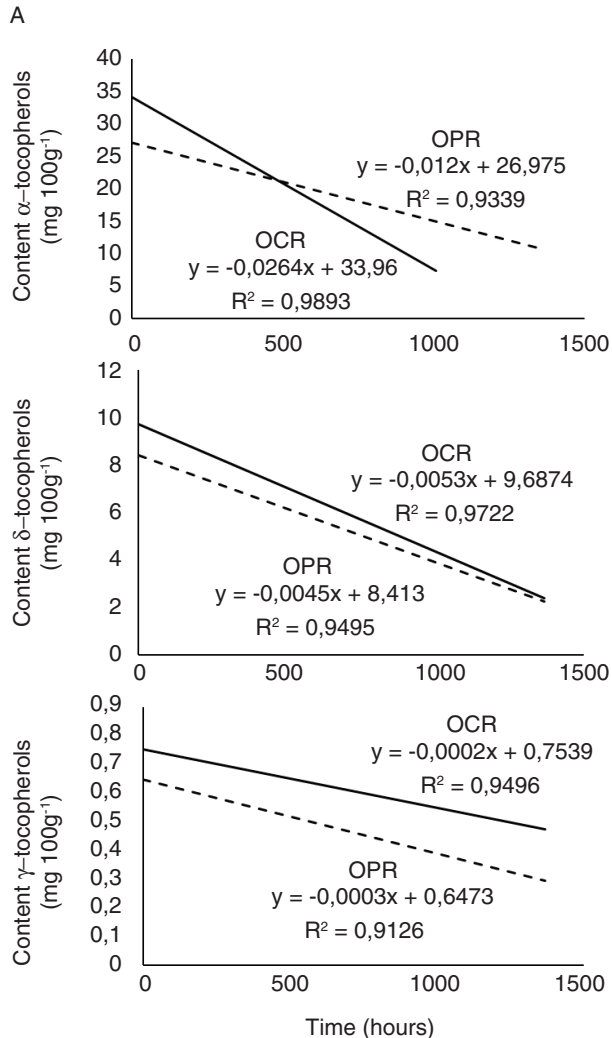

B
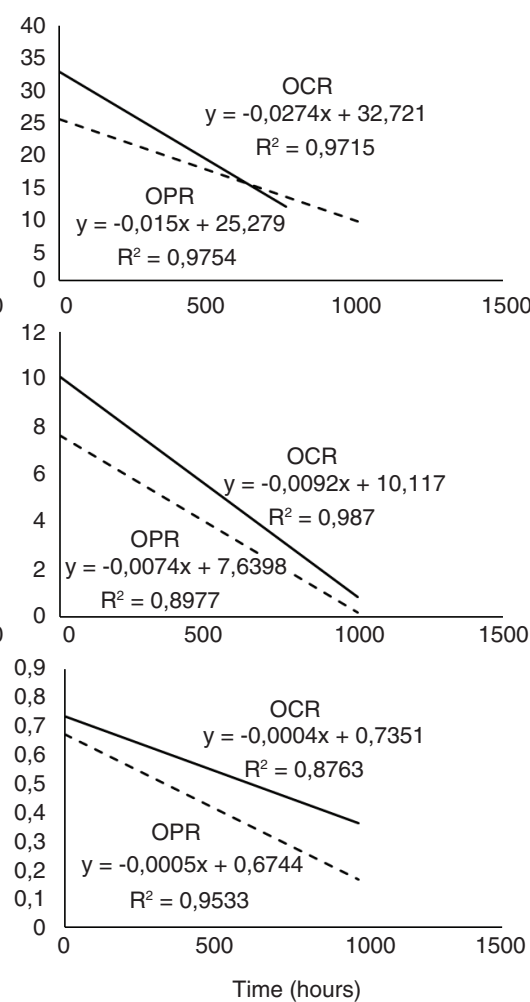

$\mathrm{C}$
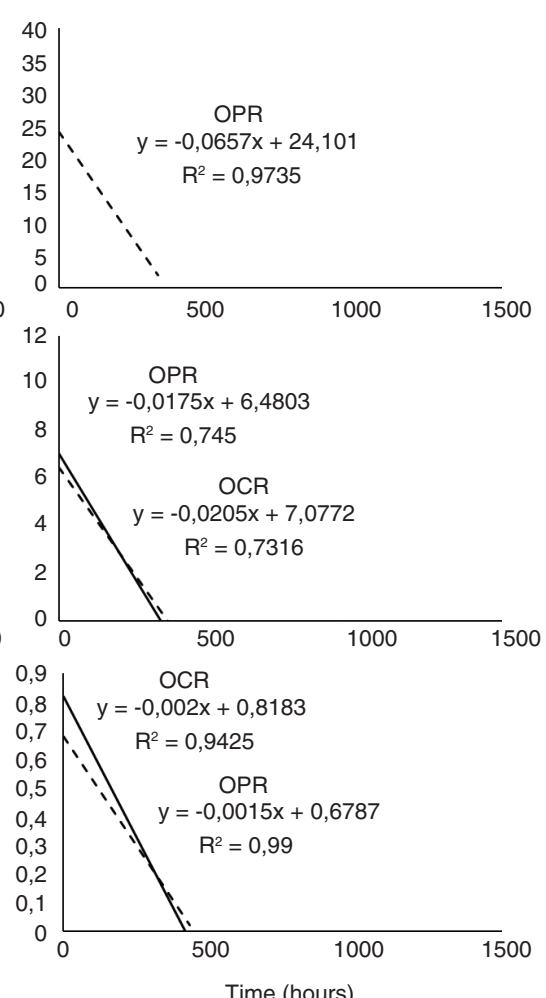

FIGURE 1. Regression analysis of $\alpha, \delta$ and $\gamma$ tocopherols in chemically (_ $)$ and physically refined rice oils (----) in relation at the different analysis temperatures, where: (a) $100^{\circ} \mathrm{C}$; (b) $140{ }^{\circ} \mathrm{C}$ and (c) $180{ }^{\circ} \mathrm{C}$. 
TABLE 2. Tocopherol contents $(n=3$, mean $\pm S D)$ in chemically refined rice oil and physically refined oil submitted to a temperature of $140{ }^{\circ} \mathrm{C}$

\begin{tabular}{|c|c|c|c|c|c|c|}
\hline \multirow[b]{2}{*}{ Time (h) } & \multicolumn{2}{|c|}{$\begin{array}{c}\alpha \text {-tocopherol } \\
\left(\mathrm{mg} \cdot 100 \mathrm{~g}^{-1}\right)\end{array}$} & \multicolumn{2}{|c|}{$\begin{array}{c}\gamma \text {-tocopherol } \\
\left(\mathbf{m g} \cdot 100 \mathbf{g}^{-1}\right)\end{array}$} & \multicolumn{2}{|c|}{ 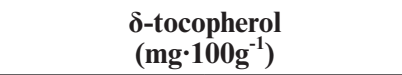 } \\
\hline & OCR* & $\mathrm{OPR}^{* *}$ & OCR* & OCR* & OPR $^{* *}$ & OCR $^{*}$ \\
\hline 0 & $32.84 \pm 1.2^{\mathrm{a}}$ & $25.67 \pm 1.6^{\mathrm{b}}$ & $9.91 \pm 0.3^{\mathrm{a}}$ & $9.22 \pm 0.3^{b}$ & $0.77 \pm 0.2^{\mathrm{a}}$ & $0.71 \pm>0.1^{\mathrm{a}}$ \\
\hline 48 & $31.19 \pm 1.8^{\mathrm{a}}$ & $24.27 \pm 1.2^{\mathrm{b}}$ & $9.88 \pm 0.3^{\mathrm{a}}$ & $7.66 \pm 0.4^{\mathrm{b}}$ & $0.75 \pm 0.1^{\mathrm{a}}$ & $0.70 \pm>0.1^{\mathrm{a}}$ \\
\hline 144 & $28.58 \pm 1.1^{\mathrm{a}}$ & $23.05 \pm 0.9^{\mathrm{b}}$ & $9.45 \pm 0.5^{\mathrm{a}}$ & $6.25 \pm 0.4^{\mathrm{b}}$ & $0.73 \pm 0.2^{\mathrm{a}}$ & $0.59 \pm>0.1^{\mathrm{a}}$ \\
\hline 240 & $25.05 \pm 0.9^{\mathrm{a}}$ & $21.15 \pm 1.4^{\mathrm{b}}$ & $7.93 \pm 0.3^{\mathrm{a}}$ & $5.01 \pm 0.2^{\mathrm{b}}$ & $0.61 \pm 0.1^{\mathrm{a}}$ & $0.53 \pm>0.1^{\mathrm{a}}$ \\
\hline 336 & $22.46 \pm 0.9^{\mathrm{a}}$ & $20.95 \pm 1.0^{\mathrm{b}}$ & $6.69 \pm 0.3^{\mathrm{a}}$ & $4.57 \pm 0.5^{\mathrm{b}}$ & $0.54 \pm 0.1^{\mathrm{a}}$ & $0.48 \pm 0.1^{\mathrm{a}}$ \\
\hline 432 & $22.27 \pm 1.1^{\mathrm{a}}$ & $18.50 \pm 0.7^{\mathrm{b}}$ & $5.79 \pm 0.2^{\mathrm{a}}$ & $3.72 \pm 0.3^{b}$ & $0.54 \pm 0.1^{\mathrm{a}}$ & $0.41 \pm>0.1^{\mathrm{a}}$ \\
\hline 576 & $18.98 \pm 1.3^{\mathrm{a}}$ & $17.12 \pm 1.2^{\mathrm{b}}$ & $4.59 \pm 0.35^{\mathrm{a}}$ & $2.81 \pm 0.2^{\mathrm{b}}$ & $0.49 \pm>0.1^{\mathrm{a}}$ & $0.37 \pm>0.1^{\mathrm{a}}$ \\
\hline 768 & $10.19 \pm 0.7^{\mathrm{a}}$ & $11.26 \pm 0.3^{\mathrm{a}}$ & $2.87 \pm 0.3^{\mathrm{a}}$ & $1.97 \pm 0.3^{\mathrm{a}}$ & $0.44 \pm>0.1^{\mathrm{a}}$ & $0.26 \pm>0.1^{\mathrm{a}}$ \\
\hline 1008 & $\mathrm{Nd}$ & $10.32 \pm 0.8^{\mathrm{a}}$ & $1.28 \pm 0.3^{\mathrm{a}}$ & $1.27 \pm 0.2^{\mathrm{a}}$ & $0.43 \pm>0.1^{\mathrm{a}}$ & $0.23 \pm>0.1^{\mathrm{a}}$ \\
\hline
\end{tabular}

Values followed by lowercase letters between the columns (OCR and OPR) do not differ from each other at $5 \%$ significance by the $\mathrm{T}$ test $(\mathrm{p}>0.05)$.

Nd- not detected

*OCR: chemically refined oil

**OPR: physically refined oil

TABLE 3. Tocopherol contents $(n=3$, men $\pm S D)$, in chemically refined rice oil and physically refined oil submitted to a temperature of $180^{\circ} \mathrm{C}$

\begin{tabular}{lcccccc}
\hline & \multicolumn{2}{c}{$\begin{array}{c}\boldsymbol{\alpha} \text {-tocopherol } \\
\left(\mathbf{m g} \cdot \mathbf{1 0 0 g}^{-1}\right)\end{array}$} & \multicolumn{2}{c}{$\begin{array}{c}\gamma \text {-tocopherol } \\
\left(\mathbf{m g} \cdot \mathbf{1 0 0 g}^{-1}\right)\end{array}$} & \multicolumn{2}{c}{$\begin{array}{c}\boldsymbol{\delta} \text {-tocopherol } \\
\left(\mathbf{m g}^{*} \mathbf{1 0 0 g}^{-1}\right)\end{array}$} \\
\cline { 2 - 7 } Time (h) & $\mathbf{O C R}^{*}$ & $\mathbf{O P R}^{* *}$ & $\mathbf{O C R}^{*}$ & $\mathbf{O C R}^{*}$ & $\mathbf{O P R}^{* *}$ & $\mathbf{O C R}^{*}$ \\
\hline 0 & $32.84 \pm 1.8^{\mathrm{a}}$ & $25.67 \pm 0.5^{\mathrm{a}}$ & $9.91 \pm 0.5^{\mathrm{a}}$ & $9.22 \pm 0.4^{\mathrm{b}}$ & $0.77 \pm 0.06^{\mathrm{a}}$ & $0.71 \pm 0.04^{\mathrm{b}}$ \\
48 & $21.75 \pm 0.6^{\mathrm{a}}$ & $18.77 \pm 0.7^{\mathrm{a}}$ & $5.68 \pm 0.4^{\mathrm{a}}$ & $4.34 \pm 0.4^{\mathrm{b}}$ & $0.74 \pm 0.06^{\mathrm{a}}$ & $0.59 \pm 0.04^{\mathrm{b}}$ \\
144 & $3.27 \pm 0.4^{\mathrm{b}}$ & $15.55 \pm 0.8^{\mathrm{a}}$ & $1.76 \pm 0.3^{\mathrm{b}}$ & $2.28 \pm 0.1^{\mathrm{a}}$ & $0.66 \pm 0.07^{\mathrm{a}}$ & $0.44 \pm 0.05^{\mathrm{b}}$ \\
240 & $\mathrm{Nd}$ & $7.56 \pm 0.8^{\mathrm{a}}$ & $0.39 \pm 0.1^{\mathrm{b}}$ & $1.17 \pm 0.1^{\mathrm{a}}$ & $0.28 \pm 0.01^{\mathrm{a}}$ & $0.28 \pm 0.02^{\mathrm{a}}$ \\
336 & $\mathrm{Nd}$ & $2.52 \pm 0.4^{\mathrm{a}}$ & $0.20 \pm 0.03^{\mathrm{b}}$ & $0.68 \pm 0.1^{\mathrm{a}}$ & $0.08 \pm 0.01^{\mathrm{b}}$ & $0.19 \pm 0.02^{\mathrm{a}}$ \\
432 & $\mathrm{Nd}$ & $\mathrm{Nd}^{\mathrm{a}}$ & $0.14 \pm 0.03^{\mathrm{a}}$ & $0.15 \pm 0.04^{\mathrm{a}}$ & $0.03 \pm 0.01^{\mathrm{a}}$ & $0.03 \pm 0.06^{\mathrm{a}}$ \\
\hline
\end{tabular}

Values followed by lowercase letters between the columns (OCR and OPR) do not differ from each other at $5 \%$ significance by the $\mathrm{T}$ test ( $\mathrm{p}>0.05)$.

Nd- not detected

*OCR: chemically refined oil

**OPR: physically refined oil

$1008 \mathrm{~h}$ of heating. The $\delta$-tocopherol present in the physically refined oil presented higher losses than those which occurred in the chemically refined oil, reaching a loss of $42.25 \%$ in the period of $432 \mathrm{~h}$ and of $67.61 \%$ at $1008 \mathrm{~h}$ of heating.

Thus, such as occurred at the heating temperature of $100{ }^{\circ} \mathrm{C}$, it was observed that the tocopherol content in the physically refined oil was more stable than the tocopherol content present in the chemically refined oil when heated at $140{ }^{\circ} \mathrm{C}$ (Figure 1b).

The chemically refined oil heated at $180{ }^{\circ} \mathrm{C}$ (Table 3 ) showed a rapid reduction in its content of $(\beta+\gamma)$-tocopherol, reaching a percentage of degradation of $96.06 \%$ in $240 \mathrm{~h}$ of heating. At the end of the heating period, the percentage of degradation was $98.59 \%$. At this temperature, the degradation of the $(\beta+\gamma)$-tocopherol of the physically refined oil was similar to that which occurred in the chemically refined oil.
The $\delta$-tocopherol of the chemically refined oil heated at $180{ }^{\circ} \mathrm{C}$ showed a gradual degradation throughout the period of exposure of the rice bran oil to heating, reaching a reduction of $96.10 \%$ at the period of $432 \mathrm{~h}$. The physically refined oil showed a reduction in $\delta$-tocopherol content similar to that which occurred in the physically refined oil, reaching the percentage of degradation of $95.77 \%$ at the end of the heating period (432 h).

The same occurred at heating temperatures of $100{ }^{\circ} \mathrm{C}$ and $140{ }^{\circ} \mathrm{C}$. It was observed that the tocopherols present in the physically refined oil showed higher stability than the tocopherols present in the chemically refined oil when heated at 180 ${ }^{\circ} \mathrm{C}$ (Figure 1c).

A greater reduction in the content of $\alpha$-tocopherol in the oil was observed both in the chemically and physically refined oil as it was heated at higher 
temperatures. However, at all temperatures, it was observed that the content of $\alpha$-tocopherol in the chemically refined oil showed a higher degree in the reduction of its content than in the physically refined oil, probably due to a greater concentration of $\gamma$-oryzanol in the physically refined oil.

For all treatments a significant $\mathrm{R}^{2}$ regression $(>0.7)$ was observed. It was possible to observe that as a function of time, all the tocopherols had their contents reduced and with the increase in temperature, the curve of decrease was more accentuated (Figure 1).

\section{DISCUSSION}

In accordance with Kalucka, Korczak, Elmadfa and Wagner (2005) and Player et al., (2006), the rapid degradation in $\alpha$-tocopherol resulted in secondary reactions of the radical tocoferoxil with hydro-peroxides or fatty acids which were not oxidized to generate more radicals. However, the initial tocopherol molecule may have also reacted with hydro-peroxides to form radical peroxil. In accordance with the same authors, both reactions accelerated lipid oxidation reactions.

As observed in $\alpha$-tocopherol, as the temperature increased, a higher degradation rate of the $(\beta+\gamma)$ and $\delta$-tocopherols occurred. Once again, the $(\beta+\gamma)$ and $\delta$-tocopherols present in the physically refined oil showed higher stability than the $(\beta+\gamma)$ - and $\delta$-tocopherols present in the chemically refined oil.

Therefore, $\alpha$-tocopherol showed lower stability when compared with the other tocopherols, which is in agreement with the results found by Player et al., (2006) and Lampi and Kamal-Eldin (1998). The order of degradation at $100{ }^{\circ} \mathrm{C}$ for the physically refined oil was: $(\beta+\gamma)->\alpha->\delta$-tocopherol, and at $140{ }^{\circ} \mathrm{C}$ the order of degradation was: $(\beta+\gamma)->\delta->$ $\alpha$-tocopherol. Only at $180{ }^{\circ} \mathrm{C}$ the order of the degradation rate was: $\alpha->(\beta+\gamma)->\delta$-tocopherol, also in agreement with the results found by Player et al., (2006) and Lampi and Kamal-Eldin (1998).

The highest stability shown by $\delta$-tocopherol may be due to its lack of capacity to donate its phenolic hydrogen to the free radicals. According to Kalucka et al., (2005), the high stability of the $\delta$-tocopherol can be associated with its smaller anti-oxidant effect when compared to $\alpha$-tocopherol, which is oxidized more rapidly into the tocopherol radical and participates in chain reactions that result in the acceleration of oxidation. Thus, $\delta$-tocopherol is more stable because it does not participate so easily as $\alpha$-tocopherol in secondary reactions with hydroperoxides, mainly at higher temperatures.

According to Steel et al., (2005), the rate of tocopherol degradation demonstrates that $\alpha$ - and $\gamma$-tocopherols are destroyed more rapidly than $\beta$ and $\delta$-tocopherols present in soybean oil heated at $180{ }^{\circ} \mathrm{C}$ for $10 \mathrm{~h}$.
However, the physically refined oil showed higher tocopherol stability in all temperatures when compared to the chemically refined oil, indicating that the oryzanols and other compounds present in the oil may have an influence on the extension of the oxidative induction period and consequently, in the stability of the oil subjected to heating.

These important natural antioxidants (tocopherols) are decreased during each step of refining and markedly reduced during deodorizing, a process of chemical refining (Chu and Lin, 1993). Some investigators (Tasan and Demirci, 2005; Alpaslan et al., 2001; Ferrari et al., 1996) reported similar observations to ours on total tocopherol loss in oil obtained from the chemical refining process. In physical refining, the steam distillation stage causes the greatest overall reduction in total tocopherol content. In contrast to physical refining, the degumming-neutralizing stage causes the greatest overall reduction in total tocopherol content during chemical refining. In the refining process, it is especially important to maintain appropriate control during the deodorizing/distillation and degummingneutralizing stages.

Ko et al., (2003), observed that short periods of heating of rice bran oil, both in a microwave oven as well as an electric oven, heated at temperatures of $170{ }^{\circ} \mathrm{C}, 180^{\circ} \mathrm{C}$ and $190^{\circ} \mathrm{C}$ caused losses in tocopherols in heating periods over $20 \mathrm{~min}, 5 \mathrm{~min}$ and $3 \mathrm{~min}$, respectively.

In a study carried out by Rennick and Warner (2006), evaluating the degradation of the $\alpha$-tocopherol in soybean and sunflower oils, it was observed that the content of $\alpha$-tocopherol presented a high reduction level at the beginning of the heating period at $180^{\circ} \mathrm{C}$ in oils enriched with $\alpha$-tocopherol. After $30 \mathrm{~h}$ of heating, $\alpha$-tocopherol had already been totally degraded, while the soybean oil, without the addition of $\alpha$-tocopherol, still showed $7 \%$ of its initial concentration.

The concentration of $\alpha$-tocopherol in samples of olive oil was monitored during thermal oxidation at $60{ }^{\circ} \mathrm{C}$ and $100{ }^{\circ} \mathrm{C}$ (Nissiotis and TasioulaMargari, 2002). Under these conditions, the authors observed that at the end of $100 \mathrm{~h}$ of heating at 100 ${ }^{\circ} \mathrm{C}, \alpha$-tocopherol had been totally degraded and during the same period at $60{ }^{\circ} \mathrm{C}, 60.36 \mathrm{mg} \cdot \mathrm{kg}_{-}{ }^{1}$ of $\alpha$-tocopherol were detected in the oil.

\section{CONCLUSIONS}

At temperatures of 100,140 and $180{ }^{\circ} \mathrm{C}$ the degradation of tocopherols occurred, which increased considerably with the increase in heating temperature in both oils. There was a higher degradation of tocopherols in chemically refined oil than in physically refined oil at all heating temperatures.

Through this study, a loss in natural antioxidants during the use of rice oil in the preparation of food was evaluated and the loss in natural antioxidants 
in rice oil as a function of the refining process was verified.

\section{ACKNOWLEDGMENTS}

National Council - Scientific and Technological Development and the Coordination of Upper Level Personal Perfecting of Brazil, Indústria Riograndense de Óleos Vegetais and to Helmut Tessmann, Brazil.

\section{REFERENCES}

Alpaslan MS, Tepe S, Fiimsek O. 2001. Effect of refining processes on the total and individual tocopherol content in sunflower oil. Int. J. Food Sci. and Tech. 36, 737-739. https://doi.org/10.1111/j.1365-2621.2001.00523.x

Azlan A, Ismail M, Abdul Hamid A. 2008. Extraction and determination of oryzanol in rice bran of mixed herbarium UKMB; AZ 6807: MR 185, AZ 6808: MR 211, AZ6809: MR 29. ASEAN F. J. 15, 89-96.

Chu YH, Lin JY. 1993. Factors affecting the content of tocopherol in soybean oil. J. Am. Oil Chem. Soc. 70, 1263-1268. https://doi.org/10.1007/BF02564239

Cunha SC, Amaral JS, Fernandes JO, Oliveira MBPP. 2006. Quantification of tocopherols and tocotrienols in Portuguese olive oils using HPLC with three different detection systems. J. Agric. Food Chem. 54, 3351-3356. https://pubs.acs.org/doi/abs/10.1021/jf053102n

Ferrari RA, Schulte E, Esteves WL, BrühlK D, Mukherjee J. 1996. Minor constituents of vegetable oils during industrial processing. Amer. Oil Chem. Soc. 73, 587-592. https:// doi.org/10.1007/BF02518112

Flohé RB. 2006. Bioactivity of vitamin E. Nutr. Res. Rev. 19, 174-186. https://doi.org/10.1017/S0954422407202938

Kalucka MN, Korczak J, Elmadfa I, Wagner KH. 2005. Effect of $\alpha$ - and $\delta$-tocopherol on the oxidative stability of a mixed hydrogenated fat under frying conditions. Eur. Food Res. Technol. 221, 291-297. https://doi.org/10.1007/ s00217-005-1161-0

Ko SN, Kim CJ, Kim CT, Kim H, Chung SH, Lee SM, Yoon HH, Kim IH. 2003. Changes of vitamin E content in rice bran with different heat treatment. Eur. J. Lipid Sci. Technol. 105, 225-228. https://doi.org/10.1002/ejlt.200390045

Lampi AM, Kamal-Eldin A. 1998. Effect of $\alpha$ - and $\gamma$-tocopherols on thermal polymerization of purified high-oleic sunflower triacylglycerols. J. Am. Oil Chem. Soc. 75, 1699-1703. https://doi.org/10.1007/s11746-998-0319-x

Martins PF. 2006. Estudos e experimentos para a concentração de tocoferóis e fitosteróis por meio da destilação molecular. Tese (Doutorado em Engenharia Química), Universidade estadual de Campinas, Faculdade de Engenharia Química, Campinas, Brasil, pp. 224.

Morrissey PA, Sheehy JA 1999. Optimal nutrition: vitamin E. Proc. Nutr. Soc. 58, 459-468. https://doi.org/10.1017/ S0029665199000609
Nissiotis M, Tasioula-Margari M. 2002. Changes in antioxidant concentration of virgin olive oil during thermal oxidation. Food Chem. 77, 371-376. https://doi.org/10.1016/ S0308-8146(02)00113-9

Nolasco SM, Aguirrezábal LAN, Crapistec GH. 2004. Tocopherol oil concentration in field-grown sunflower is accounted for by oil weight per seed. J. Am. Oil Chem. Soc. 81, 1045-1051. https://doi.org/10.1007/s11746-004-1020-6

Pestana VR, Zambiazi RC, Mendonça CR, 2008a. Farelo de arroz: características, benefícios à saúde e aplicações. Boletim Cерра 26, 29-40. https://doi.org/10.5380/cep. v26i1.11789

Pestana VR, Zambiazi RC, Mendonça CR, Bruscatto MH, Lerma-Garcia MJ, Ramis-Ramos G. 2008b. Quality Changes and Tocopherols and $\gamma$-Orizanol Concentrations. J. Am. Oil Chem. Soc. 85, 1013-1019. https://doi. org/10.1007/s11746-008-1300-4

Pestana VR, Zambiazi RC, Mendonça CR, Bruscatto MH, Ramis-Ramos G. 2009. Influencia del procesado industrial sobre las características químico-físicas y contenido en lípidos y antioxidantes del salvado de arroz. Grasas Aceites 60, 184-193. https://doi.org/10.3989/gya.075108

Player ME, Kim HJ, Lee HO, Min DB. 2006. Stability of $\alpha$-, $\gamma$ - or $\delta$ - tocopherol during soybean oil oxidation. J. Food Sci. 71, 456-460. https://doi.org/10.1111/j. 1750-3841.2006.00153.x

Rennick KA, Warner K. 2006. Effect of elevated temperature on development of tocopherol quinones in oils. J. Agric. Food Chem. 54, 2188-2192. https://doi.org/10.1021/ jf0520793

Romero N, Robert P, Masson L, Ortiz J, González K, Tapia K, Dobarganes C. 2007. Effect of $\alpha$-tocopherol, $\alpha$-tocotrienol and rosa mosqueta shell extract on the performance of antioxidant-stripped canola oil (Brassica sp.) at high temperature. Food Chem. 104, 383-389. https://doi.org/10.1016/j. foodchem.2006.11.052

Rosli WIW, Babji AS, Aminah A, Foo SP, Malik ABD. 2006. Vitamin e contents of processed meats blended with palm oils. J. Food Lipids 13, 186-198. https://doi. org/10.1111/j.1745-4522.2006.00044 x

Salem EG, El Hissewy A, Agamy NF, El Barry DA. 2014. Assessment of the quality of bran and bran oil produced from some Egyptian rice varieties. The Journal of the Egyptian Public Health Association 89, 29-34. https://doi. org/10.1097/01.EPX.0000443988.38424.9d

Statsoft 2004. Inc. Statistica for windows. Versão 7.0. Tulsa, OK.

Steel CJ, Dobarganes MC, Barrera-Arellano D. 2005. The influence of natural tocopherols during thermal oxidation of refined and partially hydrogenated soybean oils. Grasas Aceites 56, 46-52. https://doi.org/10.3989/gya.2005.v56. i1.133

Tasan M, Demirci M. 2005. Total and individual tocopherol contents of sunflower oil at different steps of refining. Eur. Food Res. Technol. 220, 251-254. https://doi.org/10.1007/ s00217-004-1045-8

Zambiazi R. 1997. The role of endogenous lipid components on vegetable oil stability. Tesis (Doctorado), Food and Nutritional Sciences Interdepartmental Program, University of Manitoba. Manitoba, Canadá, pp.304. 